\title{
Diminished Response to Interleukin-10 and Reduced Antibody-Dependent Cellular Cytotoxicity of Cord Blood Monocyte-Derived Macrophages
}

\author{
CHRISTIAN GILLE, BÄRBEL SPRING, LENA J. TEWES, JÜRGEN LÖFFLER, GÜNTHER E. DANNECKER, \\ MICHAEL K. HOFFMANN, MARTIN EICHNER, CHRISTIAN F. POETS, AND THORSTEN W. ORLIKOWSKY
}

\begin{abstract}
University Children's Hospital [C.G., B.S., C.F.P., T.W.O.], 72076 Tuebingen, Germany; University Hospital of General, Visceral, and Transplantation Surgery [L.J.T.], 72076 Tuebingen, Germany; University of Wuerzburg [J.L.], Medizinische Klinik II, 97070 Wuerzburg, Germany; Olgahospital [G.E.D.], 70176 Stuttgart, Germany; Department of Immunology and Microbiology [M.K.H.], New York Medical College, Valhalla, NY 10595; Department of Medical Biometry [M.E.], University of Tuebingen, 72070 Tuebingen, Germany
\end{abstract}

\begin{abstract}
Monocyte-derived macrophage (MФ) subsets are generated by antagonistic induction pathways. A helper МФ-type $(\mathrm{Mh}-\mathrm{M} \Phi)$ is induced by interferon gamma (IFN- $\gamma$ ), whereas a cytotoxic $\mathrm{M} \Phi$-type (Mc-M $\Phi$ ), induced by interleukin-10 (IL-10), is a potent mediator of antibody-dependent cellular cytotoxicity (ADCC). Compared with $\mathrm{M} \Phi$ from healthy adults [peripheral blood monocyte-derived macrophages (PBMФ)], cord blood MФ (CВMФ) were found less capable of generating Mh-MФ. Here we tested the hypothesis that their generation of Mc-M $\Phi$ via IL-10 is also impaired. М $\Phi$ surface markers were phenotyped. IL-10 protein and mRNA production were detected after stimulation $[\alpha \mathrm{CD} 3$ monoclonal antibody $(\mathrm{mAb})]$. СBM $\Phi$ or MФ-depleted mononuclear cells of adults and CD4-targeting antibodies as models for ADCC were added. In cord blood, we found diminished $\alpha \mathrm{CD} 3$-induced IL-10 protein and mRNA production $(p<$ 0.05 versus adults). Basal CD16 and HLA-DR expressions on CBMФ of preterm and full-term neonates were lower $(p<0.05$ versus PBMФ). IL-10 had reduced effects on CD16 up- and HLA-DR down-modulation on $\mathrm{CBM} \Phi(p<0.05$ versus $\mathrm{PBM \Phi ).} \mathrm{CD4-}$ directed receptor modulation and deletion were reduced in the presence of $\mathrm{CBM} \Phi$ ( $p<0.05$ versus PBMФ). IL-10 failed to enhance their ADCC capacity, which was in contrast to $\operatorname{PBM\Phi ~}(p<0.05)$. These data suggest that $\mathrm{CBM} \Phi$ have an impaired cytotoxic capacity via lower sensitivity toward IL-10. (Pediatr Res 60: 152-157, 2006)
\end{abstract}

Q ualitative characteristics of immune responses are regulated by immune cell subsets through their production of distinct cytokines. TH1 cytokines, e.g. IFN- $\gamma$, play an important role in the inflammatory response and promote cell-mediated responses against bacteria, whereas TH2 cytokines, e.g. IL-10, induce antibody synthesis and promote immunoregulatory signals. Evidence exists that the neonatal period is characterized by a TH2-dominated immune response with a hyporesponsive inflammatory component $(1,2)$. In contrast, clinical observation reveals a more severe para-

Received October 31, 2005; accepted March 29, 2006.

Correspondence: Thorsten W. Orlikowsky, M.D., Univ.-Kinderklinik Tübingen, Germany, Calwerstr. 7, 72076 Tübingen, Germany; e-mail: thorsten.orlikowsky@med.unituebingen.de

DOI: $10.1203 / 01 . p d r .0000228345 .58509 .7 b$ infectious systemic inflammatory response in neonates than in children and adults, often with detrimental sequelae (3). Consistent with these findings, neonates show an enhanced capacity to produce proinflammatory cytokines during infections (4) and inflammatory diseases, e.g. bronchopulmonary dysplasia (5) or periventricular leukomalacia (6).

Cytokines orchestrate $\mathrm{T}$ cell immune responses either directly or indirectly via antigen presenting cells, e.g. blood monocytes or $М \Phi$. Via antagonistic cytokine induction pathways, at least two $М \Phi$ subsets, displaying distinct phenotypes and functions, have been distinguished (7): IFN- $\gamma$ generates a costimulatory helper $\mathrm{M} \Phi$-type $(\mathrm{Mh})$ which expresses and up-regulates B7 family receptors (CD80, B7-1 and CD86, B7-2) (8). Its engagement of T cell CD28 family molecules influences T cell survival, activation, and TH1/TH2 cytokine production [for review, see Salomon and Bluestone (9)]. In contrast, IL-10 not only mediates inhibitory and immunoregulatory signals, but induces a cytotoxic $\mathrm{M} \Phi$-type $(\mathrm{Mc})(8)$, which fails to up-regulate HLA-DR and B7 molecules. Mc-M $\Phi$ instead express Fc-gamma III receptors (CD16) in high density (7). Mc-M $\Phi$ are potent mediators that destroy antibody-coated, e.g. virus-infected, cells by ADCC via induction of apoptosis (10).

We found СВМ $\Phi$ less capable of generating Mh-М $\Phi$ due to diminished IFN- $\gamma$ effects on B7 molecules, thereby inhibiting $\mathrm{M} \Phi$-dependent $\mathrm{T}$ cell activation $(11,12)$. Here, we tested the hypothesis that their generation of Mc-M $\Phi$ via IL-10 in cord blood is also impaired.

\section{MATERIALS AND METHODS}

Patients. The study protocol was approved by the Ethics Committee of the University of Tuebingen. All mothers had given written consent before they went into labor. Randomly selected, adult healthy donors served as controls.

\footnotetext{
Abbreviations: ADCC, antibody-dependent cellular toxicity; $\boldsymbol{\alpha C D 4}, \mathrm{mAb}$ anti-CD4 monoclonal antibody; СВMФ, cord blood monocyte-derived macrophages; CBMNCs, cord blood mononuclear cells; gp120, HIV glycoprotein 120 ; IFN- $\boldsymbol{\gamma}$, interferon gamma; $\mathbf{M \Phi}$, monocyte-derived macrophages; PBMФ, peripheral blood monocyte-derived macrophages; PBMNCs, peripheral bloodmononuclear cells
} 
All term neonates were delivered spontaneously and did not exhibit signs of infection, as defined by the clinical status, and, if necessary, C-reactive protein. Ten preterm neonates (medium gestational age $29.5 \mathrm{wk}$; range, 25.5-32.6 wk; medium birth weight, $1350 \mathrm{~g}$; range, 650-1690 g) were delivered for maternal reasons [cervix insufficiency $(n=5)$, preeclampsia $(n=4)$, or placental ablation $(n=1)]$. Maternal antibiotics and antenatal steroids (up to $4 \mathrm{wk}$ before labor) were given to seven of 10 preterm neonates, four infants were from multiparous pregnancies. Although six preterm infants were treated with antibiotics, none developed serological or clinical signs of early-onset bacterial infection. Mothers with amnion infections or prolonged labor were excluded. Umbilical cord blood was drawn by puncture with a sterile needle and placed in heparin-coated tubes (100 IE $/ \mathrm{mL}$ blood) immediately following cord ligation.

Cell cultures. Peripheral blood and cord blood mononuclear cells (PBMNCs and CBMNCs) were isolated by density gradient centrifugation (Biochrom AG, Berlin, Germany). Washed cells were resuspended in VLE RPMI 1640 (Biochrom), containing 10\% FCS (Biochrom). Cells were counted in an ultraplane Neubauer hemocytometer, placed at $2 \times 10^{6}$ cells $/ \mathrm{mL}$ in flat-bottom, 24-well cell culture plates (Costar, Bodenheim, Germany) and incubated at $37^{\circ} \mathrm{C}$.

Preparation of mononuclear cell subsets. To separate $М \Phi$ from lymphocytes, cells were plated at $3 \times 10^{6}$ cells per $1.5 \mathrm{~mL}$ in $60 \times 15$-mm culture vessels (NoK4-3802-4, BD Biosciences, Heidelberg, Germany) in the incubator and allowed to adhere for $60 \mathrm{~min}$. Nonadherent cells were gently removed by repeatedly pipetting $500 \mu \mathrm{L}$ of RPMI buffer into the cultures. Remaining adherent cells were twice thoroughly washed and used as a source of MФ. Usually, 95\% of adherent cells were viable and 85\% expressed CD14. Remaining CD14- cells were negative for the natural killer cell receptor CD56. To further eliminate contaminating nonadherent $M \Phi$, the procedure described above was repeated with the nonadherent cell fraction. Usually, $<1 \% \mathrm{CD} 14^{+} \mathrm{M} \Phi$ were found in the nonadherent fraction after this adherence cycle, as determined by fluorescence-activated cell sorter analysis.

Co-culture experiments. M $\Phi$-enriched adherent cells $\left(1 \times 10^{6} / 0.5 \mathrm{~mL}\right)$ and $\mathrm{M} \Phi$-depleted nonadherent cells $\left(2 \times 10^{6} / 0.5 \mathrm{~mL}\right)$ were mixed. Nonadherent cell fractions were not pooled from different donors. To equalize allogeneic effects, СВM $\Phi$ and with nonadherent, nonirradiated cells of a second adult donor. In none of the coculture experiments did we see any significant $\mathrm{T}$ cell deletion in the absence of deleting reagents, as observed earlier (10). Anti-CD3-mediated T cell proliferation required the presence of $\mathrm{M} \Phi$ or the addition of a co-mitogenic anti-CD28 mAb (L293 low azide, $1 \mu \mathrm{g} / \mathrm{mL}$, BD Biosciences,) and was assessed by Vybrant CFDA SE Cell Tracer Kit (Molecular Probes, Eugene, $\mathrm{OR}$ ) according to the manufacturer's protocol.

IL-10 quantification by electroimmunoassay. IL-10 was quantified in supernatants using human IL-10 OptEIA (BD-PharMingen, Freiburg, Germany) according to the manufacturer's instructions. The OD was measured photometrically at $450 \mathrm{~nm}$ in an enzyme-linked immunosorbent assay reader Spectra (Tecan, Frankfurt, Germany). Samples were analyzed in duplicate and blotted against a standard curve (Mathcad Professional 2000). The assay detected values as low as $7.8 \mathrm{pg} / \mathrm{mL}$.

Flow cytometry. A FACScan flow cytometer (BD Biosciences) was used. To prevent nonspecific binding, cells were incubated with $10 \%$ human serum on ice for $10 \mathrm{~min}$ before staining with fluorescein-isothiocyanate-, phycoerythrin-, or isotype-specific immunoglobulin-labeled $\mathrm{mAb}$ for $20 \mathrm{~min}$ in the dark. М $\Phi$ were gated by forward scatter, side scatter, and CD14 expression. Dead lymphocytes were discriminated by propidium iodide (PI) (Molecular Probes, $5 \mu \mathrm{g} / \mathrm{mL}, 5 \mathrm{~min}$ ). PI-negative cells were counted, double stained for CD4/CD3 and CD8/CD3, and analyzed for expression of CD4 and CD8. The percentage of deleted $\mathrm{T}$ cells was determined as previously described (13) applying the formula: percentage of deleted $\mathrm{T}$ cells $=1-$ remaining $\mathrm{T}$ cells $=1-(\mathrm{T}$ cells cultured with deleting reagent at day $2: \mathrm{T}$ cells cultured without deleting reagent at day 2) $\times 100$.

mRNA quantification. For RNA extraction, the MagNA Pure LC RNA Isolation Kit I (Roche, Mannheim) was used as described previously (14). Synthesis of cDNA was performed using the First Strand cDNA Synthesis Kit (Roche). Amplification and quantification of cDNA were performed using a standard LightCycler protocol and external standardization, based on fluorescence resonance energy transfer (FRET) with specific oligonucleotides (14). External standards consisting of purified polymerase chain reaction products were quantified by spectral photometry, followed by serial dilution to obtain defined amounts of input copy numbers. All results were normalized against the expression of the housekeeping gene ALAS (5-aminolevulinate synthase gene)

Reagents. To target CD4 $\mathrm{T}$ cells that we used a chimeric humanized antibody (anti-CD4 mAb, $\alpha \mathrm{CD} 4$; ch 412, $1 \mu \mathrm{g} / \mathrm{mL}$; gift from Gerd Riethmuller, Munich, Germany) and immune complexes, consisting of recombinant HIV-1 gp120SF2 (1 $\mu \mathrm{g} / \mathrm{mL}$, kindly provided by K. Steimer, Chiron
Biocine, Emeryville, CA) and serum from an HIV seropositive donor (New York Medical College, Valhalla, NY; final dilution 1:1000) as source of anti-gp120 ( $\alpha \mathrm{gp} 120)$ antibody as previously described (15). The T cell mitogen anti-CD3 $(\alpha \mathrm{CD} 3 \mathrm{mAb}$; OKT3, $5 \mu \mathrm{g} / \mathrm{mL})$ was used as a soluble antibody and purchased from Ortho Diagnostics (Raritan, NJ). Antibodies to CD14 (MФP9), CD80 (L307.4), HLA-DR (L243), CD3 (SK7), CD56 (NCAM16.2), CD8 (SK1), CD28 (L293), and immunoglobulin (Ig)-matched controls (IgG1, IgG2b) were purchased from BD Biosciences. Remaining CD4 T cells were detected by OKT4 (Ortho), which is a non-cross reactive antibody to ch412 (10).

Data display and statistical analysis. Fluorescence intensities were determined and the nonspecific background staining was subtracted. Results are expressed as mean $\pm \mathrm{SD}$. Statistical analysis was performed by using the decadic logarithm of the values of CD16, HLA-DR, and CD80. Using analysis of variance, it was examined whether the variables were influenced by IL-10 or age (both nominal effects). Using an analysis of covariance, it was examined whether the decadic logarithm of numbers of remaining $\mathrm{T}$ cells were influenced by time or the origin of the blood. The variable "patient" was nested and modeled as a random effect; an interaction between "patient" and "day" was considered. Values of $p<0.05$ were considered statistically significant. Statistical analysis was performed using the Sigmaplot 2000 software for Windows (SPSS, Chicago, IL).

\section{RESULTS}

IL-10 production after stimulation with a $T$ cell mitogen. To compare IL-10 production in mononuclear cells of cord blood and peripheral blood of adults (CBMNCs and PBMNCs), we used an in vitro stimulation with $\alpha \mathrm{CD} 3 \mathrm{mAb}$ (Fig. 1). Supernatants were analyzed at 6, 12, 24, and $48 \mathrm{~h}$. Unstimulated mononuclear cells produced low IL-10 concentrations after $48 \mathrm{~h}$. We found a substantial increase in IL-10 protein production in PBMNCs, which was in contrast to CBMNCs $(p<0.05$; Fig. $1 A)$ and also evident at the mRNA transcriptional level after $24 \mathrm{~h}$ (Fig. $1 B$ ). In the presence of $\mathrm{M} \Phi$ (Fig. $1 C$ ), the addition of a co-mitogen (anti-CD28 mAb, $\alpha \mathrm{CD} 28 \mathrm{mAb}$ ) to $\alpha \mathrm{CD} 3 \mathrm{mAb}$ markedly enhanced $\mathrm{T}$ cell proliferation in PBMNCs and CBMNs (not shown), but induced only little IL-10 production in CBMNCs after $48 \mathrm{~h}$ (Fig. $1 C$ ). In the absence of $\mathrm{M} \Phi$ (Fig. $1 D$ ), IL-10 production of PBMNCs was lower in the stimulated groups $(p<0.05$ versus corresponding groups with $\mathrm{M} \Phi$ ).

IL-10-mediated effects on CD16 and HLA-DR expression on $M \Phi$. To analyze IL-10-mediated effects on M $\Phi$ phenotypes, CD16 and HLA-DR expression on CBM $\Phi$ of preterm and full-term neonates, as well as on $Р B M \Phi$, were assessed after stimulation for $48 \mathrm{~h}$ (Fig. 2). Basal receptor expressions were reduced on СВMФ $(p<0.05$ versus $\mathrm{PBM} \Phi)$, with lower densities on preterm neonates $(p<0.05$ versus full-term neonates). IL-10 up-regulated CD16 dose dependently on РВMФ $(p<0.05$ versus unstimulated PBM $\Phi)$, but only slightly on CBM $\Phi$ ( $p>0.05$; Fig. $2 A$ ). IL-10-induced HLA-DR down-modulation on PBM $\Phi$ was dose dependent as well and more pronounced $(p<0.05$ versus unstimulated PВМФ), whereas this effect was only marginal on СВМФ $(p>0.05$ versus unstimulated СВMФ; Fig. $2 B$ ). For both parameters, IL-10-mediated effects were not different between CВM $\Phi$ of term and preterm neonates $(p>0.05)$. М $\Phi$ survival did not differ between groups, but in the presence of IL-10, MФ cell death increased from $15 \%$ to $26 \%(500 \mathrm{ng} / \mathrm{mL}$ IL-10) after 48 h (not shown).

MФ-mediated CD4-directed T cell deletion. As shown previously, IL-10 enhances cytotoxic $\mathrm{M} \Phi$ function by facilitating $\mathrm{T}$ cell deletion via $\operatorname{ADCC}(7,10)$. Before analyzing this 

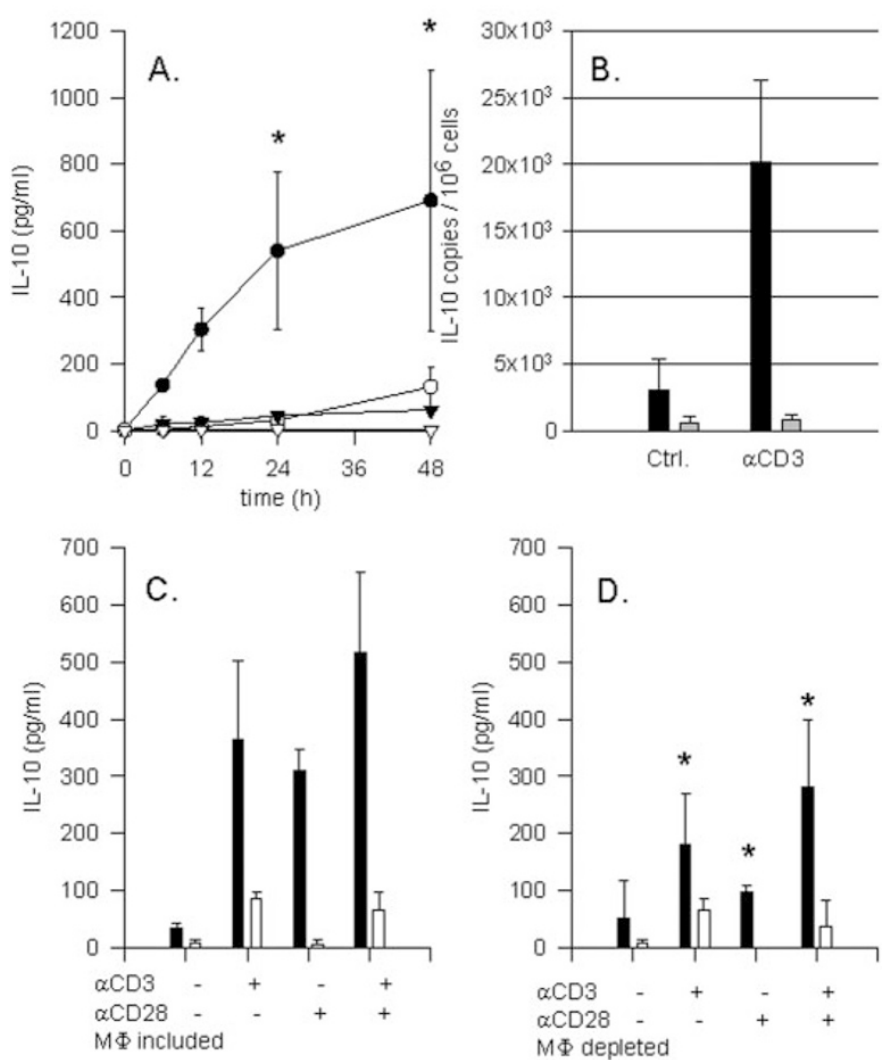

Figure 1. IL-10 protein and mRNA production: $4 \times 10^{6} / \mathrm{mL}$ PBMNCs (solid columns) or CBMNCs (open columns) were incubated without (triangles) or with (circles) $\alpha \mathrm{CD} 3 \mathrm{mAb}(5 \mu \mathrm{g} / \mathrm{mL})$ for $48 \mathrm{~h}$. Supernatants were analyzed for IL-10 protein. For 6 and $12 \mathrm{~h}$ five experiments and for 24 and $48 \mathrm{~h}$ eight experiments are depicted $(A) ; * p<0.05$. Cells were probed for IL-10 mRNA; three experiments are depicted $(B)$. In the presence $(C)$ or absence $(D)$ of $M \Phi$, PBMNCs (black bars) and CBMNCs (white bars) were additionally stimulated with $\alpha \mathrm{CD} 28 \mathrm{mAb}(1 \mu \mathrm{g} / \mathrm{mL})$ for $48 \mathrm{~h}(n=3) ;{ }^{*} p<0.05 v s$ presence of $\mathrm{M} \Phi$.

function, we assessed the basal ADCC capacity of PBM $\Phi$ and $\mathrm{CBM} \Phi$, directed against CD4 T cells. MФ-depleted PBMNC of one adult donor were incubated either with СВMФ or PBM $\Phi$ of a second unrelated adult donor. We chose this system to avoid a potentially different sensitivity toward ADCC-mediated apoptosis between neonatal and adult $\mathrm{T}$ cells. $\mathrm{M} \Phi$ were added in different concentrations in the absence or presence of a CD4 T cell-directed deleting antibody $(\alpha \mathrm{CD} 4 \mathrm{mAb})$ for $48 \mathrm{~h}$ (Fig. 3). CD4 $\mathrm{T}$ cell deletion was dependent on the presence of $\mathrm{M} \Phi$ and their concentrations added. Although both $\mathrm{CBM} \Phi$ and $\mathrm{PBM} \Phi$ induced CD4 T cell deletion ( $p<0.05$ versus $\alpha \mathrm{CD} 4$-treated MФ-depleted PBMNCs), it was stronger in the presence of $P B M \Phi$ in all МФ: lymphocyte ratios $(p<0.05$ versus СВMФ, Fig. $3 A)$. The deletion was specific for CD4 $\mathrm{T}$ cells; CD8 T cells remained unaffected (Fig. 3B).

CD4 $\mathrm{T}$ cell apoptosis-preceding events were shown to be CD4 receptor down-modulation and co-modulation of other surface receptors e.g. CD3 and CD28 (8). These phenomena were found on the remaining CD4 T cells with both $\mathrm{M} \Phi$ subsets (Fig. 4). In the presence of РВМФ versus СВМФ, CD4 down-modulation was 63 versus $25 \%$, CD3 comodulation was 35 versus $13 \%$, and $\mathrm{CD} 28$ co-modulation

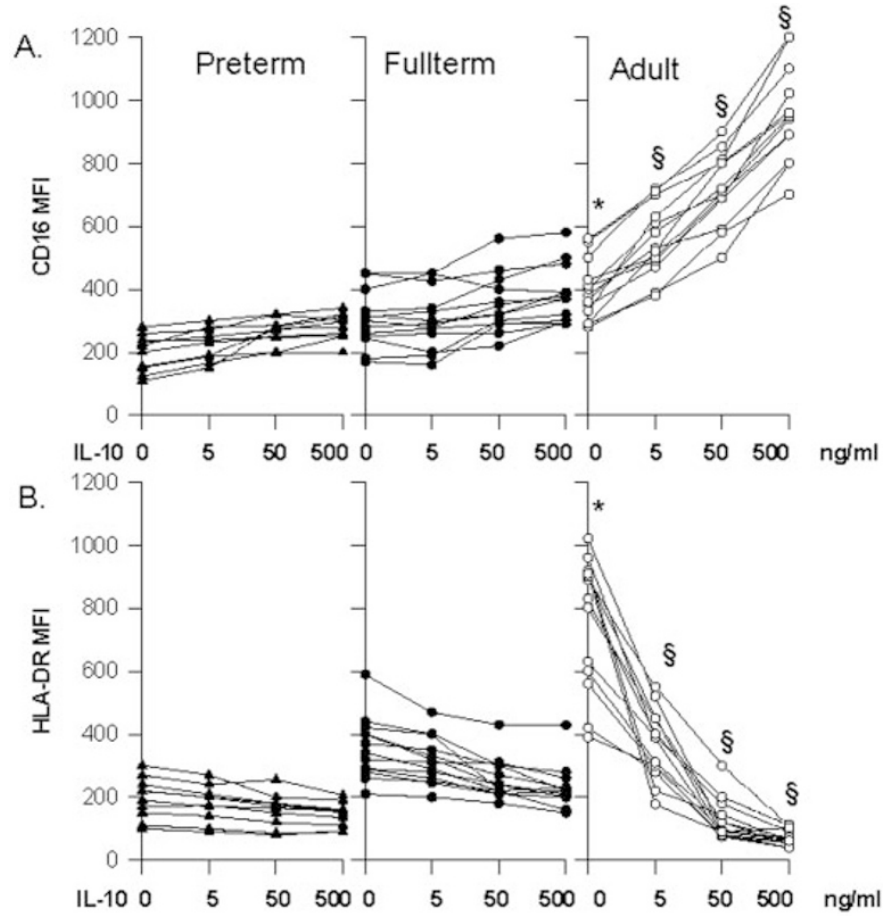

Figure 2. CD16 and HLA-DR expression profiles: $2 \times 10^{6} \mathrm{M} \Phi$ of preterm neonates $(n=10$, solid triangles), full-term neonates $(n=13$, solid circles $)$, and adults ( $n=13$, open circles) were treated with IL-10 for $48 \mathrm{~h}$ (concentrations indicated). CD16 (A) and HLA-DR $(B)$ densities are expressed (arbitrary fluorescence intensity units above baseline per donor). ${ }^{*} p<0.05$ preterm $v s$ full term $v s$ adult; $\$ p<0.05$ effect of IL-10 on adults $v s$ full-term and preterm neonates.

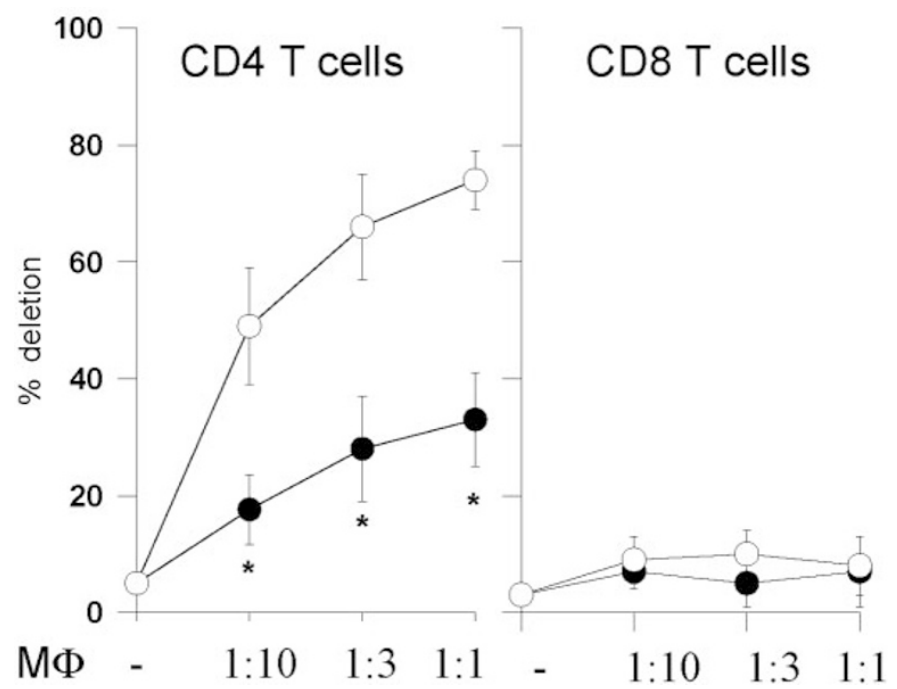

Figure 3. МФ-mediated CD4-directed T cell deletion: $2 \times 10^{6}$ nonadherent cells of one adult donor were co-incubated with $2 \times 10^{5}, 6 \times 10^{5}, 2 \times 10^{6}$ either СВМФ (full-term neonates, solid circles) or PBM $\Phi$ of a second adult donor (open circles) in the presence of $\alpha \mathrm{CD} 4(1 \mu \mathrm{g} / \mathrm{mL})$ for $48 \mathrm{~h}$. The remaining cells were counted, assayed for CD4 and CD8 and are expressed as percentage of deleted cells $(n=3, * p<0.05$ РВMФ vs CВMФ).

$40 \%$ versus $66 \%$ (Table 1 , all $p<0.05$ ). Neither downmodulation nor deletion occurred in the absence of $\alpha \mathrm{CD} 4 \mathrm{mAb}$ (not shown).

Effect of IL-10 on enhancement of MФ cytotoxicity. To compare IL-10 cytotoxicity, M $\Phi$-depleted PBMNCs of one adult donor were cocultured either with СВMФ or РВМФ of 

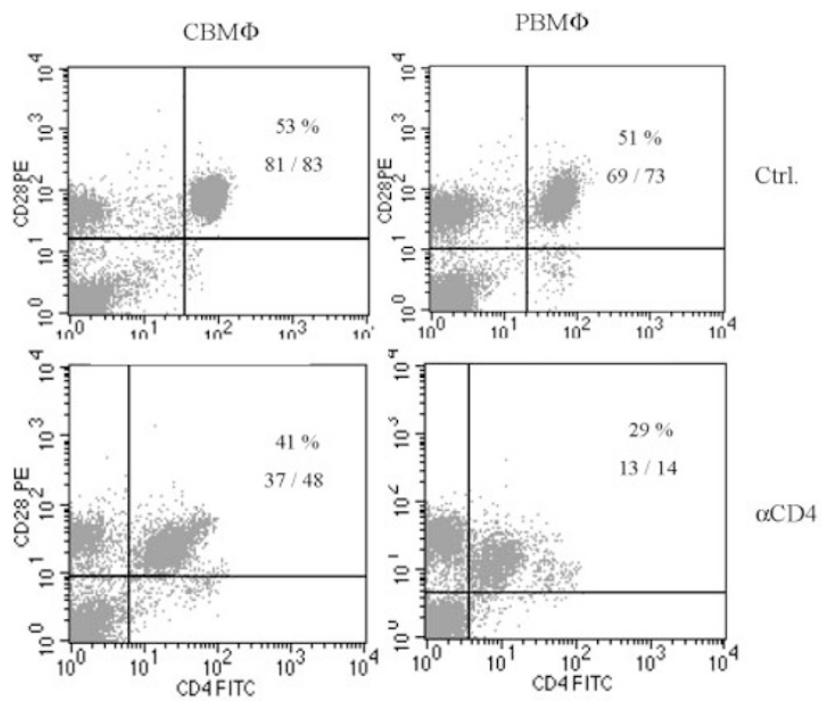

Figure 4. Receptor-modulation on CD4 T cells: $2 \times 10^{6} \mathrm{M} \Phi$-depleted PBMNCs from one healthy adult donor were cocultured with $1 \times 10^{6}$ either СВМФ (full-term neonate, left) or PВМФ (right) from a second adult donor in the absence (top) or presence (bottom) of $\alpha \mathrm{CD} 4 \mathrm{mAb}(1 \mu \mathrm{g} / \mathrm{mL}$ ) for $48 \mathrm{~h}$. Samples were double stained for CD4 and CD28 expression. Numbers represent the percentage of CD4 T cells and their CD4 (left) and CD28 (right) mean fluorescence intensities. No down-modulation occurred in the absence of $\mathrm{M} \Phi$ or the CD4-negative fraction (not shown).

Table 1. Receptor down-modulation on CD4 T cells

\begin{tabular}{lrcrc}
\hline & \multicolumn{2}{c}{$\begin{array}{c}\text { M } \Phi \text {-depleted PBMNCs } \\
\text { Coculture }\end{array}$} & \multicolumn{2}{c}{$\begin{array}{c}\text { M } \Phi \text {-depleted PBMNCs } \\
+ \text { CBM } \Phi\end{array}$} \\
\hline Antibody & No mAb & $\alpha \mathrm{CD} 4 \mathrm{mAb}$ & No mAb & $\alpha \mathrm{CD} 4 \mathrm{mAb}$ \\
CD4 (MFI) & $63(20)$ & $23(8)$ & $64(15)$ & $48(10)^{*}$ \\
CD3 (MFI) & $131(20)$ & $80(17)$ & $137(23)$ & $119(25)^{*}$ \\
CD28 (MFI) & $73(14)$ & $25(12)$ & $91(14)$ & $55(10)^{*}$ \\
\hline
\end{tabular}

MФ-depleted PBMNCs $\left(2 \times 10^{6}\right)$ were cocultured with $1 \times 10^{6} \mathrm{PBM} \Phi$ from a second adult donor or CBM $\Phi$ in the presence or absence of $\alpha \mathrm{CD} 4$ $\mathrm{mAb}(1 \mu \mathrm{g} / \mathrm{mL})$. CD4, CD3, and CD28 expression on CD4 T cells was assessed after $48 \mathrm{~h}$. Three experiments are shown (mean $\pm \mathrm{SD}$ ). ${ }^{*} p<0.05 \mathrm{vs}$ $\alpha \mathrm{CD} 4 \mathrm{mAb}$-treated group with PВМФ. No differences were seen on CD4 ${ }^{-}$ cells (not shown).

a second unrelated adult donor for $48 \mathrm{~h}$ as described above. Targets again were CD4 $\mathrm{T}$ cells, forming $\mathrm{M} \Phi$ conjugates either by $\alpha \mathrm{CD} 4 \mathrm{mAb}$ or immune complexes, consisting of immune-complexed HIV-envelope protein gp120. IL-10 was added to both groups (Fig. 5). Again, СВMФ and РВМФ induced $\mathrm{T}$ cell deletion via antibody and immune complexes $(p<0.05$ versus corresponding groups without deleting substances, not shown). РBM $\Phi$ were more effective though in eliminating CD4 $\mathrm{T}$ cells by both, $\alpha \mathrm{CD} 4 \mathrm{mAb}$ and immune complexes $(p<0.05$ versus CВMФ; first versus third column). Addition of IL-10 increased M $\Phi$ cytotoxicity in cultures with $\mathrm{PBM} \Phi(~ p<0.05$ versus deleting substance only), which was in contrast to CВMФ $(p>0.05)$. IL-10 $(50 \mathrm{ng} / \mathrm{mL})$ did not affect CD4 or M $\Phi$ survival (not shown).

\section{DISCUSSION}

The scope of our experiments was to determine the production of IL-10 and its influence on phenotype and cytotoxic function of СВМФ versus РВМФ. We first found a diminished IL-10 protein and mRNA production in dCD3-

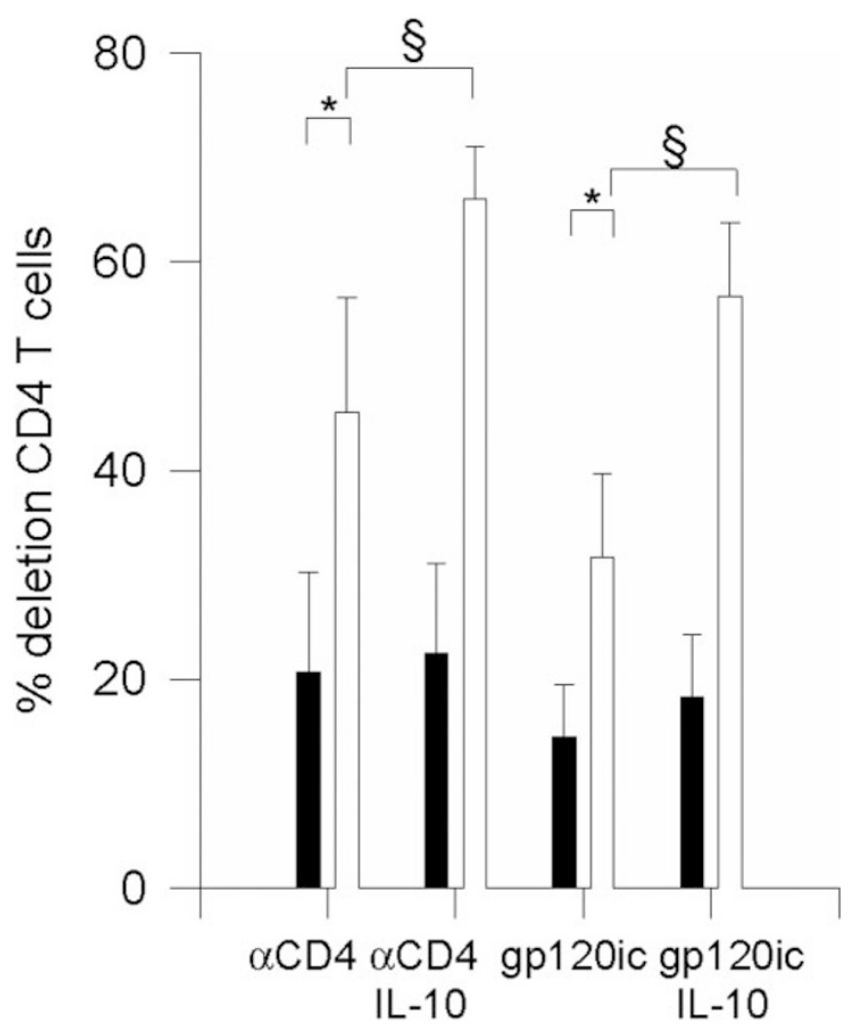

Figure 5. Effects of IL-10 on the cytotoxic capacity of MФ: $2 \times 10^{6}$ MФ-depleted PBMNCs from one adult donor were cocultured with $1 \times 10^{6}$ РВМФ (open columns) from a second adult donor or СВM $\Phi$ (full-term neonate, solid columns) in the absence or presence of $\alpha \mathrm{CD} 4(1 \mu \mathrm{g} / \mathrm{mL})$, or gp120/ $\alpha$ gp120 immune complexes and IL-10 $(50 \mathrm{ng} / \mathrm{mL})$ for $48 \mathrm{~h}$. Remaining T cells were counted and phenotyped $(n=4)$. No changes in the CD8 T cell fraction were seen (not shown); * $p<0.05$ РВMФ vs СВМФ, $\S p<0.05$ IL-10 $+\alpha$ CD4 or gp120/ $\alpha$ gp120 (gp120ic) $v s ~ \alpha C D 4$ or gp120/ $\alpha$ gp120.

stimulated CBMNCs (Fig. 1). Second, the basal CD16 and HLA-DR expression on, and the cytotoxic capacity mediated by CВM $\Phi$ were reduced (Figs. 2-4). Third, IL-10-mediated effects on СBM $\Phi$ phenotype (Fig. 2) and their cytotoxic function (Figs. 4 and 5, Table 1), were impaired. Taken together, our data suggest CBMNCs to produce less IL-10 and CВMФ to be less sensitive toward IL-10 and less capable of generating Mc-M $\Phi$ in our experimental setup. These results are consistent with recent work suggesting that the neonatal immune response is not only deficient in promoting activation (11) but also inhibition $(4,5)$.

IL-10 is produced by various cells, including monocytes, $\mathrm{M} \Phi$, and T cells. Although neonates are capable of producing considerable amounts of IL- 6 and IL- 10 when induced via endotoxins, e.g. during sepsis $(16,17)$, results of neonatal IL-10 production are conflicting and depend on the stimulation used (17-19). We found a profoundly diminished IL-10 mRNA and protein production in CBMNCs stimulated with anti-CD3 (Fig. 1). Anti-CD3-stimulated neonatal T cells already were shown to produce significantly less IL-10 than $\mathrm{T}$ cells from adults (18). A more detailed characterization of IL-10 production by naïve (CD45RA) versus memory (CD45RO) CD4 $\mathrm{T}$ cells revealed the latter subset to produce significantly more IL-10 (18). This subset is virtually absent in healthy neonates and may partly explain the reduced IL-10 
production in CBMNCs (Fig. $1 A-C$ ), most prominent in the absence of MФ (Fig. 1D). Moreover, IL-10 production of naïve neonatal CD45RA T cells (18) and monocytes (19) were found to be reduced in similar experimental settings as well as after stimulation with endotoxin $(4,19)$. Although the addition of a co-mitogen (anti-CD28 mAb) increased T cell proliferation in the presence of $\mathrm{M} \Phi$ (not shown), we did not find a significant increase in IL-10 production compared with antiCD3 only (Fig. $1 C$ ), which may be due to a relatively high mitogen concentration $(5 \mu \mathrm{g} / \mathrm{mL})$.

CD16 and HLA-DR expression on CBM $\Phi$ were lower in preterm than in full-term neonates (Fig. 2), confirming earlier reports $(12,20,21)$. Conflicting phenotypic results showing equivalent or even increased CD16 expression on M $\Phi$ from preterm neonates (22) may be related to maternal steroids or other medication. Glucocorticoids were shown to selectively deplete $\mathrm{CD} 6^{+}$monocytes in adults (23). Because antenatal steroids were administered to $70 \%$ of our preterm infants (Fig. 2), further analysis on their influence on $М \Phi$ survival is required. $\mathrm{CD}_{16}{ }^{+} \mathrm{M} \Phi$ represent a differentiated $\mathrm{M} \Phi$ subset that does not produce IL-10 $(24,25)$ but strongly induces ADCC via CD95L and CD16 (26). CD16 ${ }^{+} \mathrm{M} \Phi$ increase in neonatal sepsis (27) and are involved in parainfectious tissue destruction in adults (28). Taking the vulnerability of neonatal tissues into account, the reduced MФ CD16 expression and induction in preterm neonates may be of advantage in vivo.

To our knowledge, neonatal and adult $М \Phi$-mediated ADCC, analyzed by flow cytometry on a single-cell basis (Table 1, Figs. 3-5), have not yet been compared. Previous experiments detecting ADCC by ${ }^{51} \mathrm{Cr}$ release revealed diminished cytotoxicity of CBM $\Phi$ toward chicken erythrocytes when conjugates were formed by heteroantibodies via Fcgamma I receptors (CD64) (29). Our ADCC model targets CD4 $\mathrm{T}$ cells and involves Fc-gamma III (CD16) because ADCC is blocked by CD16 receptor blockade (15).

CD4 $\mathrm{T}$ cell receptor densities declined after conjugate formation with CD4-specific antibodies (Fig. 4, Table 1), confirming earlier reports (30). Co-modulation of surface receptors is a preceding event of $\mathrm{T}$ cell apoptosis (31) and involves the CD95/CD95L system (10). Because MФ express and secrete CD95L (32) and IL-10 is capable of up-regulating CD95L (33), it is conceivable that neonatal MФ do not primarily destroy lymphocytes that exhibit (auto)antibodies on their surface, but may form conjugates with nonlymphoid antibody-reactive tissues and induce apoptosis (34). Increased CD95L concentrations were found in healthy neonates (35) and maternal or neonatal inflammatory diseases (36). Therefore, a reduced $\mathrm{CBM} \Phi$ cytotoxicity could be a means to counterbalance apoptotic hyperreactions.

It is conceivable that our results are influenced by cells in the nonadherent fraction, which may have secondary effects on $\mathrm{M} \Phi$, or by the purification process via adherence. The latter may preactivate more mature monocytes and, although negative for natural killer cells, also select nonmonocytic cells. However, when we negatively selected $M \Phi$ by magnetic bead depletion, the differences in ADCC capacity between CВМФ and PBMФ remained, suggesting the role of the CD14 negative cells in the $\mathrm{M} \Phi$-enriched environment to be of minor impact.

IL-10 was found to promote only minimal effects on neonatal $\mathrm{T}$ cells with respect to induction of B-cell helper functions compared with adults (18). Its inhibitory effect on proinflammatory cytokine production was shown to be lower in preterm infants than in adults, indicating a reduced IL-10 response (4). Our data suggest $\mathrm{CBM} \Phi$ to be less sensitive toward IL-10 with respect to CD16 up- and HLA-DR downregulation (Fig. 2), although this may be balanced by the genuinely lower receptor densities in vivo. In contrast to PBMФ, we found no IL-10-mediated ADCC enhancement on CBMФ (Fig. 5). Whether these findings are due to lower IL10 receptor densities, which are crucial in IL-10 signaling (37), compromised IL-10 binding properties to the receptor, and/or altered intracellular signal transduction in elucidated.

With respect to IL-10-mediated effects, our data should be interpreted with caution. We used an in vitro system with relatively small sample sizes. In addition, for reasons of sample volumes required, we have not yet longitudinally investigated kinetics of cord and peripheral blood of newborns. Our model may therefore not properly reflect the neonatal situation several days postnatally. This was a heterogeneous group of preterm neonates, and although none of them developed early-onset infection, we cannot rule out effects of multiparous pregnancy or maternal antibiotics or antenatal steroids on their immunologic profile. To examine these parameters, as well as interindividual variations, further experiments elucidating pathophysiological mechanisms are required.

In conclusion, our results provide further evidence that the neonatal immune response is not dominated by either pro- or anti-inflammatory reaction patterns but that the plasticity of both sides is restricted compared with adults. As a consequence, a diminished stability and following hyperreactions to both sides are to be expected.

\section{REFERENCES}

1. Marodi L 2002 Deficient interferon-gamma receptor-mediated signaling in neonatal macrophages. Acta Paediatr Suppl 91:117-119

2. Rowen JL, Smith CW, Edwards MS 1995 Group B streptococci elicit leukotriene B4 and interleukin-8 from human monocytes: neonates exhibit a diminished response. J Infect Dis 172:420-426

3. Romero R, Maymon E, Pacora P, Gomez R, Mazor M, Yoon BH, Berry SM 2000 Further observations on the fetal inflammatory response syndrome: a potential homeostatic role for the soluble receptors of tumor necrosis factor alpha. Am J Obstet Gynecol 183:1070-1077

4. Schultz C, Temming P, Bucsky P, Gopel W, Strunk T, Hartel C 2004 Immature anti-inflammatory response in neonates. Clin Exp Immunol 135:130-136

5. Oei J, Lui K, Wang H, Henry R 2002 Decreased interleukin-10 in tracheal aspirates from preterm infants developing chronic lung disease. Acta Paediatr 91:1194-1199

6. Dammann O, Leviton A 1997 A maternal intrauterine infection, cytokines, and brain damage in the preterm newborn. Pediatr Res 42:1-8

7. Orlikowsky T, Wang ZQ, Dudhane A, Horowitz H, Conti B, Hoffmann MK 1997 Two distinct pathways of human macrophage differentiation are mediated by interferon-gamma and interleukin-10. Immunology 91:104-108

8. Kummerle-Deschner JB, Hoffmann MK, Niethammer D, Dannecker GE 1998 Pediatric rheumatology: autoimmune mechanisms and therapeutic strategies. Immunol Today 19:250-253

9. Salomon B, Bluestone JA 2001 Complexities of CD28/B7: CTLA-4 costimulatory pathways in autoimmunity and transplantation. Annu Rev Immunol 19:225-252

10. Orlikowsky T, Wang ZQ, Dudhane A, Horowitz H, Riethmuller G, Hoffmann MK 1997 Cytotoxic monocytes in the blood of HIV type 1-infected subjects destroy targeted T cells in a CD95-dependent fashion. AIDS Res Hum Retroviruses 13:953960 
11. Orlikowsky TW, Spring B, Dannecker GE, Niethammer D, Poets CF, Hoffmann MK 2003 Expression and regulation of B7 family molecules on macrophages (MPhi) in preterm and term neonatal cord blood and peripheral blood of adults. Cytometry B Clin Cytom 53:40-47

12. Orlikowsky TW, Dannecker GE, Spring B, Eichner M, Hoffmann MK, Poets CF 2005 Effect of dexamethasone on $\mathrm{B} 7$ regulation and $\mathrm{T}$ cell activation in neonates and adults. Pediatr Res 57:656-661

13. Orlikowsky TW, Wang ZQ, Dudhane A, Dannecker GE, Niethammer D, Wormser GP, Hoffmann MK, Horowitz HW 2001 Dexamethasone inhibits CD4 T cell deletion mediated by macrophages from human immunodeficiency virus-infected persons. J Infect Dis 184:1328-1330

14. Loeffler J, Swatoch P, Akhawi-Araghi D, Hebart H, Einsele H 2003 Automated RNA extraction by MagNA Pure followed by rapid quantification of cytokine and chemokine gene expression with use of fluorescence resonance energy transfer. Clin Chem 49:955-958

15. Dudhane A, Wang ZQ, Orlikowsky T, Gupta A, Wormser GP, Horowitz H, Kufer P, Hoffmann MK 1996 AIDS patient monocytes target CD4 T cells for cellular conjugate formation and deletion through the membrane expression of HIV-1 envelope molecules. AIDS Res Hum Retroviruses 12:893-899

16. Romagnoli C, Frezza S, Cingolani A, De Luca A, Puopolo M, De Carolis MP, Vento G, Antinori A, Tortorolo G 2001 Plasma levels of interleukin-6 and interleukin-10 in preterm neonates evaluated for sepsis. Eur J Pediatr 160:345-350

17. Rainsford E, Reen DJ 2002 Interleukin 10, produced in abundance by human newborn $\mathrm{T}$ cells, may be the regulator of increased tolerance associated with cord blood stem cell transplantation. Br J Haematol 116:702-709

18. Splawski JB, Yamamoto K, Lipsky PE 1998 Deficient interleukin-10 production by neonatal $\mathrm{T}$ cells does not explain their ineffectiveness at promoting neonatal $\mathrm{B}$ cell differentiation. Eur J Immunol 28:4248-4256

19. Chheda S, Palkowetz KH, Garofalo R, Rassin DK, Goldman AS 1996 Decreased interleukin-10 production by neonatal monocytes and $\mathrm{T}$ cells: relationship to decreased production and expression of tumor necrosis factor-alpha and its receptors. Pediatr Res 40:475-483

20. Birle A, Nebe CT, Gessler P 2003 Age-related low expression of HLA-DR molecules on monocytes of term and preterm newborns with and without signs of infection. J Perinatol 23:294-299

21. Liu E, Tu W, Law HK, Lau YL 2001 Changes of CD14 and CD1a expression in response to IL-4 and granulocyte-macrophage colony-stimulating factor are different in cord blood and adult blood monocytes. Pediatr Res 50:184-189

22. Carr R, Huizinga TW, Kleijer M, Davies JM 1992 Changes in plasma FcRIII demonstrate increasing receptor production during late pregnancy and after preterm birth. Pediatr Res 32:505-508

23. Fingerle-Rowson G, Angstwurm M, Andreesen R, Ziegler-Heitbrock HW 1998 Selective depletion of CD14+CD16+ monocytes by glucocorticoid therapy. Clin Exp Immunol 112:501-506
24. Ziegler-Heitbrock HW, Fingerle G, Strobel M, Schraut W, Stelter F, Schutt C, Passlick B, Pforte A, 1993 A The novel subset of CD14+/CD16+ blood monocytes exhibits features of tissue macrophages. Eur J Immunol 23:2053-2058

25. Frankenberger M, Sternsdorf T, Pechumer H, Pforte A, Ziegler-Heitbrock HW 1996 Differential cytokine expression in human blood monocyte subpopulations: a polymerase chain reaction analysis. Blood 87:373-377

26. Boyle JJ 2004 Human macrophages kill human mesangial cells by Fas-Linduced apoptosis when triggered by antibody via CD16. Clin Exp Immunol 137:529-537

27. Grage-Griebenow E, Flad HD, Ernst M, Bzowska M, Skrzeczynska J, Pryjma J 2000 Human MO subsets as defined by expression of CD64 and CD16 differ in phagocytic activity and generation of oxygen intermediates. Immunobiology 202:42-50

28. Skrzeczynska J, Kobylarz K, Hartwich Z, Zembala M, Pryjma J 2002 $\mathrm{CD} 14+\mathrm{CD} 16+$ monocytes in the course of sepsis in neonates and small children: monitoring and functional studies. Scand J Immunol 55:629-638

29. Stiehm ER, Roberts RL, Ank BJ, Plaeger-Marshall S, Salman N, Shen L, Fanger MW 1994 Comparison of cytotoxic properties of neonatal and adult neutrophils and monocytes and enhancement by cytokines. Clin Diagn Lab Immunol 1:342-347

30. Mittler RS, Hoffmann MK 1989 Synergism between HIV gp120 and gp120-specific antibody in blocking human T cell activation. Science 245:1380-1382

31. Wang ZQ, Dudhane A, Orlikowsky T, Clarke K, Li X, Darzynkiewicz Z, Hoffmann MK 1994 CD4 engagement induces Fas antigen-dependent apoptosis of T cells in vivo. Eur J Immunol 24:1549-1552

32. Kiener PA, Davis PM, Rankin BM, Klebanoff SJ, Ledbetter JA, Starling GC, Liles WC 1997 Human monocytic cells contain high levels of intracellular Fas ligand: rapid release following cellular activation. J Immunol 159:1594-1598

33. Barreiro R, Luker G, Herndon J, Ferguson TA 2004 Termination of antigen-specific immunity by CD95 ligand (Fas ligand) and IL-10. J Immunol 173:1519-1525

34. Gallagher SF, Peng Y, Haines K, Baksh K, Epling-Burnette PK, Yang J, Murr MM $2005 \mathrm{Fas} / \mathrm{FasL}$ play a central role in pancreatitis-induced hepatocyte apoptosis. J Gastrointest Surg 9:467-474

35. Sarandakou A, Protonotariou E, Rizos D, Soubassi L, Malamitsi-Puchner A 2003 A Soluble Fas antigen and soluble Fas ligand in early neonatal life. Early Hum Dev 75:1-7

36. Felderhoff-Mueser U, Buhrer C, Groneck P, Obladen M, Bartmann P, Heep A 2003 A Soluble Fas (CD95/Apo-1), soluble Fas ligand, and activated caspase 3 in the cerebrospinal fluid of infants with posthemorrhagic and nonhemorrhagic hydrocephalus. Pediatr Res 54:659-664

37. Ding Y, Qin L, Zamarin D, Kotenko SV, Pestka S, Moore KW, Bromberg JS 2001 Differential IL-10R1 expression plays a critical role in IL-10-mediated immune regulation. J Immunol 167:6884-6892 